\title{
Sodium and Fluid Replacement in a Chronic Renal Failure Patient after Ileostomy
}

\section{Kronik Böbrek Yetmezliği Hastasında Illeostomi Sonrası Sodyum ve Sıvı Replasmanı}

İskender EKINCI, Murat ALAY, Reha ERKOÇ, Rümeyza KAZANCIOĞLU

Department of Internal Medicine, Nephrology, Bezmialem Vakif University, Faculty of Medicine, Istanbul, Turkey

\section{ABSTRACT}

The two most common causes of short bowel syndrome in adults are Crohn's disease and mesenteric ischemia. Mesenteric ischemia is more common in hemodialysis patients than in the normal population. Ileostomy is performed after bowel resection in most mesenteric ischemia patients. Ileostomy patients lose an excessive amount of water and sodium. Sodium and fluid replacement is described in a chronic renal failure patient with ileostomy.

Key Words: Ileostomy, chronic renal failure, sodium replacement, hypovolemia

\section{ÖZET}

Erişkinlerde kısa barsak sendromu en sık Crohn hastalığı ve mezenter iskemisine bağlıdır. Mezenter iskemisi kronik hemodiyaliz hastalarında normal populasyondan daha sık görülür. Mezenter iskemisi geliştiğinde barsak rezeksiyonu yapıldıktan sonra hastaların çoğunda ileostomi açılır. İleostomili hastalarda aşırı sıvı ve tuz kaybı görülebilir. Burada ileostomili kronik böbrek yetmezliği hastasında sodyum ve sıvı replasmanı anlatılmıştır.

Anahtar Sözcükler: İleostomi, kronik böbrek yetmezliği, sodyum replasmanı, hipovolemi

\section{Giriş}

Erişkinlerde kısa barsak sendromunun Crohn hastalığından sonraki en sık nedeni mezenter iskemisidir. Mezenter iskemisi normal populasyonda nadir görülmesine rağmen kronik hemodiyalize giren hastalarda akut batın tablosu yapan sebeplerin başında gelir. Bunun sebebi hemodiyalizde yoğun ultrafiltrasyon yapılması sonucu gelişen rölatif hipovolemi ve hemodiyalizdeki hipotansiyon epizodlarının oluşturduğu dolaşım yetersizliğidir (1). Mezenter iskemisi nedeniyle barsak rezeksiyonu yapıldıktan sonra hastaların çoğunda ileostomi açılır. İleostomili hastalarda aşırı sıvı ve tuz kaybı görülür (2). Burada mezenter iskemi nedeniyle barsak rezeksiyonu yapılan ve ileostomi açılan bir hemodiyaliz hastasında sodyum ve sıvı replasmanı tedavisi anlatılmaktadır.

\section{Olgu Sunumu}

Düzelmeyen hipotansiyon nedeniyle genel cerrahi kliniğinden nefroloji kliniğimize devir alınan 53 yaşındaki erkek hasta, 20 gün önce acil servise karın ağrısı şikayeti ile başvurmuş. 13 yıldır haftada 3 gün hemodiyaliz yapılan hastanın yapılan ilk değerlendirmesinde mezenter iskemi saptanmış. İnce barsak ve omentum rezeksiyonu yapılan hastaya ileostomi açılmış. Hastanın nefroloji kliniğine yatışında fizik muayenesinde genel durumu orta, bilinci açı, koopere ve oryante idi. Turgor tonusu azalmış olan hastanın arteriyal tansiyonu 70/40 mmHg, kalp tepe atımı sayısı 96/dk, solunum sayısı 14/dk saptand. Barsak sesleri artmıştı ve batında yaygın hassasiyet mevcuttu. Kardiyak muayenesi doğaldı. Diğer sistem muayeneleri doğaldı. Laboratuar verileri Tablo 1'de gösterildiği gibiydi. 


\begin{tabular}{|c|c|c|c|}
\hline Tetkik & Sonuç & Tetkik & Sonuç \\
\hline WBC $\left(\times 10^{3} \mu / L\right)$ & 8,9 & Ürik asit (mg/dL) & 3,9 \\
\hline $\mathrm{Hgb}(\mathrm{g} / \mathrm{dL})$ & 9 & $\mathrm{Cl}(\mathrm{mg} / \mathrm{dL})$ & 9,6 \\
\hline Hct (\%) & 29 & $\mathrm{Mg}(\mathrm{mg} / \mathrm{dL})$ & 1,8 \\
\hline Plt $\left(x 10^{3} \mu / L\right)$ & 171 & Protein Total $(\mathrm{g} / \mathrm{dL})$ & 5,5 \\
\hline $\mathrm{Na}$ (mmol/L) & 131 & Albumin (g/dL) & 2,8 \\
\hline $\mathrm{K}(\mathrm{mmol} / \mathrm{L})$ & 3,5 & $\mathrm{LDH}(\mathrm{U} / \mathrm{L})$ & 239 \\
\hline BUN (mg/dL) & 11 & $\mathrm{ESR}(\mathrm{mm} / \mathrm{sa})$ & 94 \\
\hline Üre (mg/dL) & 24 & $\mathrm{CRP}(\mathrm{mg} / \mathrm{dL})$ & 3,6 \\
\hline Kreatinin (mg/dL) & 5,3 & $\mathrm{Fe}(\mathrm{ug}(\mathrm{dL})$ & 81 \\
\hline $\mathrm{Ca}(\mathrm{mg} / \mathrm{dL})$ & 6,9 & DBK (ug/dL) & 154 \\
\hline $\mathrm{P}(\mathrm{mg} / \mathrm{dL})$ & 1,7 & Ferritin (ng/mL) & 1451 \\
\hline
\end{tabular}

WBC: Lökosit sayısı, Hgb: Hemoglobin, Hct: Hematokrit, Plt: Platelet sayısı, Na: Sodyum, K:Potasyum, BUN: Kan üre azotu, Ca: Kalsiyum, P: Fosfor,Cl: Klor, Mg: Magnezyum, LDH: Laktat Dehidrogenaz, ESR: Eritrosit Sedimentasyon Hızı, CRP: C Reaktif Protein, Fe: Demir, DBK: Demir Bağlama Kapasitesi

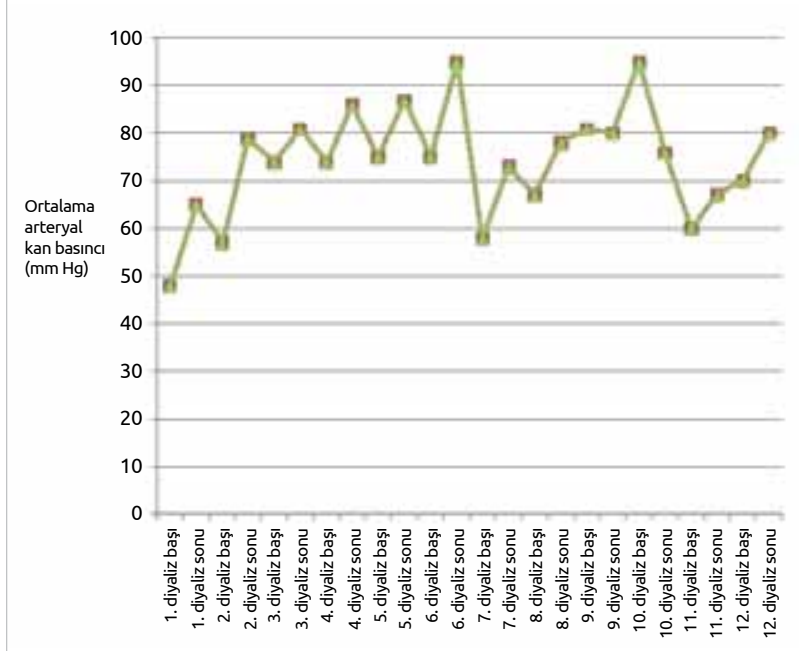

Şekil 1. Hemodiyaliz esnasında arteriyal tansiyon değerleri

Hemodiyaliz esnasinda mevcut hipotansif durumunun daha da derinleşmesi üzerine sıvı replasmanı ve dopamin infüzyonu başlandı. Dopamin infüzyonu altında arteriyal tansiyonu 60/40 $\mathrm{mmHg}$ olan hastanın hipotansiyonu (Şekil-1), ileostomiden aşıı sıvı kaybı ve barsak rezeksiyonu kaynaklı malabsorbsiyona bağlandı. Hastaya günde $18 \mathrm{gr}$ tuz (sıvı içinde ve 4 saatte bir olacak şekilde), 4000 cc mayi replasmanı ve motilite önleyici tedavi başlandı. İki diyaliz arasında sürekli kilo kaybettiği gözlenen (Şekil 2) hastaya verilen oral tuz miktarı arttırıldı. Oral $72 \mathrm{gr}$ tuz ve parenteral sıvı replasmanına rağmen düzelme görülmeyen hastanın tedavisine parenteral $\mathrm{NaCl}$ de eklendi. Hipoalbuminemi, hipofosfatemi ve hipokalsemisi için albümin, fosfor ve kalsiyum replase edildi. Hastadaki sıvı açı̆̆ı ve elektrolit kayıpları, hastanın klinik bulguları değerlendirilerek ileostomiden olan kayıplara bağlandı. Takiplerinde iki diyaliz arasında kilo kaybı olmadığı gözlenen hastanın oral ve parenteral $\mathrm{NaCl}$ desteği azaltılarak kesildi. Hasta yatışının $35^{\prime}$ inci gününde taburcu edildi.

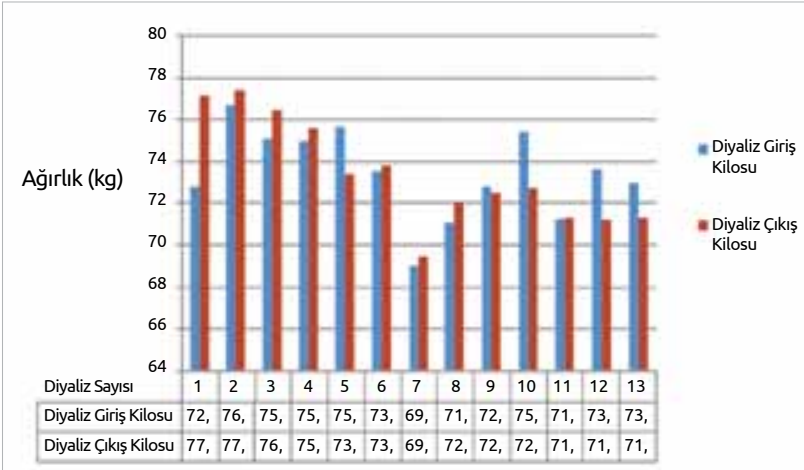

Şekil 2. íki diyaliz arasında hastanın vücut ağırlığı takibi

\section{Tartışma}

Kısa barsak sendromunun erişkinlerde en sık sebepleri; crohn hastalığı, vasküler yetmezlik ve radyasyon hasarı sebebiyle yapılan cerrahi rezeksiyonlardır. Diğer sebepler ise volvulus, travma ve neoplazmlardır (3). Bizim hastamızda da mezenter iskemisi nedeniyle ince barsak rezeksiyonu yapılmıştı.

Sıvı ve elektrolitlerin absorbsiyonlarının çok büyük bir kısmı ileum ve kolonda olur (3). Jejunostomi sonrası kalan ince barsak segmenti $<200 \mathrm{~cm}$ olan hastalara sıklıkla parenteral tuz, kalsiyum ve magnezyum replasmanı gerekir. Eğer geriye kalan ince barsak segmenti $<100 \mathrm{~cm}$ ise parenteral beslenme desteği de gerekir $(3,4)$. Hastamızda saptanan sıvı açığı ve elektrolit kaybının rezeksiyon sonrası gelişen malabsorbsiyona bağlı olduğunu düşündük ve sıvı, sodyum ve eksik saptanan diğer elektrolitleri yerine koyduk.

Kronik böbrek yetmezliği hastalarına rutin uygulamada sodyumdan fakir diyet ve oral sıvı alımının kısıtlanması önerilir. Fakat hastamızda ileostomiden aşırı sodyum ve sıvı kaybı olması üzerine, bu açığı kapatmak için oral-parenteral sodyum ve sıvı replasmanı yapıldı. Replasman tedavisi sonrası hastamızın iki diyaliz seansı arasında kuru ağırlığını koruduğu gözlendi.

\section{Sonuç}

İleostomi açılan hastalarda ciddi emilim kusuruna bağlı olarak büyük miktarda sıvı ve tuz kaybının olabileceği unutulmamalı ve hastalar bu açıdan izlenmelidir.

Informed Consent: Written informed consent was obtained from the patient who participated in this case.

Peer-review: Externally peer-reviewed.

Author Contributions: Concept - İ.E., M.A., R.K., R.E.; Design - İ.E., M.A.,R.K.,R.E.; Supervision - İ.E., M.A., R.K., R.E.; Data Collection and/ or Processing - İ.E.; Analysis and/or Interpretation - İ.E.,R.K.; Literature Review - İ.E.; Writing - İ.E.,R.K.; Critical Review - S.Ö.

Conflict of Interest: No conflict of interest was declared by the authors.

Financial Disclosure: The authors declared that this case has received no financial support. 
Hasta Onamı: Yazılı hasta onamı bu çalışmaya alınan hastadan alınmıştır.

Hakem Değerlendirmesi: Dış bağımsız

Yazar Katkıları: Fikir - İ.E., M.A., R.K., R.E.; Tasarım - İ.E., M.A., R.K., R.E.; Denetleme - İ.E., M.A., R.K.,R.E.; Veri Toplanması ve/veya İslemesi İ.E.; Analiz ve/veya Yorum - İ.E., R.K.; Literatür Taraması İ.E.; Yazıyı Yazan - İ.E., R.K.; Eleștirel İnceleme - S.Ö.

Çıkar Çatışması: Yazarlar çıkar çatışması bildirmemişlerdir.

Finansal Destek: Yazarlar bu çalışma için finansal destek almadıklarını beyan etmişlerdir.

\section{Kaynaklar}

1. Hachache T, Milongo R, Kuentz F, Guergour M, Maynard C, Meftahi $\mathrm{H}$, et al. Mesenteric ischemia in hemodialyzed patients. Presse Med 1997; 26: 410-3.

2. Sacher P, Hirsig J, Gresser J, Spitz L. The importance of oral sodium replacement in ileostomy patients. Prog Pediatr Surg 1989; 24: 226-31. [CrossRef]

3. Nightingale JM, Lennard-Jones JE. The short bowel syndrome: what's new and old? Dig Dis 1993; 11: 12-31. [CrossRef]

4. Ladefoged K, Hessov I, Jarnum S. Nutrition in short-bowel syndrome. Scand J Gastroenterol Suppl 1996; 216: 122-31. [CrossRef] 